Plant Tissue Cult. \& Biotech. 22(1): 59-64, 2012 (June)

$\overline{\text { PTC\&B }}$

\title{
Hyaluronic Acid Can be a New Plant Growth Regulator for Hybrid Cymbidium Micropropagation
}

\section{Naruemol Kaewjampa, Kazuhiko Shimasaki ${ }^{1}$ and Syeda Jabun Nahar}

The United Graduate School of Agriculutral Sciences, Ehime Unversity, 3-5-7 Tarumi, Matsuyama, Ehime, 790-8556 Japan

Key words: Protocorm-like body, Hyaluronic acid, Growth regulator, Cymbidium

\begin{abstract}
Present authors investigated the effect of two biopolymer hyaluronic acid (HA9) and chitosan (Chitosan $\mathrm{H}$ ), and $\mathrm{N}^{6}$-benzyladenine (BA) supplemented with modified MS on organogenesis in protocorm-like bodies (PLBs) of a Cymbidium cultivar. The percentages of PLB formation from cultures showed $100 \%$ in all treatments except for control (82.7\%), $0.1 \mathrm{mg} / \mathrm{l} \mathrm{HA9}$ (93.3\%) and $10 \mathrm{mg} / \mathrm{l}$ Chitosan $\mathrm{H}(93.3 \%)$ treatments. Addition of $0.1 \mathrm{mg} / \mathrm{l} \mathrm{HA} 9$ to culture medium was highly efficient for PLB multiplication. Both $10 \mathrm{mg} / \mathrm{l} \mathrm{HA} 9$ and $1.0 \mathrm{mg} / \mathrm{l} \mathrm{BA}$ significantly increased the number of shoots in cultures. The maximum percentage of shoot $(100 \%)$ was obtained at $1.0 \mathrm{mg} / \mathrm{l}$ chitosan $\mathrm{H}$. Increase in fresh weight showed higher values at BA treatments. Information gained from this study shows that hyaluronic acid (HA9) which is new additive for plant tissue culture act as growth regulator for hybrid Cymbidium micropropagation.
\end{abstract}

\section{Introduction}

Cymbidium is commercially important orchids together with Phalaenopsis, Dendrobium and Cattleya (Teixeira et al. 2006a). Thus, many attempts have been made to develop methodologies, culture media and culture condition for the micropropagation of Cymbidium (Morel 1960, Shimasaki and Uemoto 1990, Nayak et al. 2002, Teixeira et al. 2006a, 2006b, Hossain et al. 2010). To increase the efficiency of in vitro techniques, plant growth regulators are frequently used for orchids (Arditti and Ernst 1993). Plant growth regulators such as BA improve plant regeneration from PLBs in Cymbidium (Shimasaki and Uemoto 1990, Nasiruddin et al. 2003). Recently, chitosan has been reported to act as a plant

${ }^{1}$ Author for correspondence: Faculty of Agricuture, Kochi University, B200 Monobe, Nankoku, Kochi, 783-8502 Japan. <shim@kochi-u.ac.jp>. 
growth regulator and considered to elicit the induction of plant defense mechanisms in many plant (Ben-Shalom et al. 2003, Photchanachai et al. 2006). One kind of elicitor chitosan positively affects the number of PLBs in Dendrobium and Cymbidium in vitro (Shimasaki et al. 2003, Nge et al. 2006, Pornpienpakdee et al. 2010). Thus, authors have hypothesis that some other elicitors may transmit signals which induce organogenesis in orchid cultures. The elicitor hyaluronic acid (HA) is potent agent for suppressing disease in cucumber, tomato and pepper (Park et al. 2008). The functions of HA include cell adhesion and migration, dynamic processes that are mediated through interaction with extracellular matrix components, regulation of protein secretion, gene expression and cell proliferation and differentiation (Scott 1992, Fraser et al. 1997). Present authors reported that some biopolymers enhanced orchid organogenesis and growth in vitro (Kaewjampa et al. 2010, Jabun et al. 2011). However, there is no information available for comparative effects of BA and HA as a plant growth regulator for Cymbidium micropropagation. Therefore, this study investigated the effect of HA for the possibility to apply as new growth regulator by comparison of BA and chitosan.

\section{Materials and Methods}

Approximately $5 \mathrm{~mm}$ in length PLBs derived from meristem cultures of Cymbidium Waltz 'Idol' which proliferated in modified MS (Shimasaki and Uemoto, 1990) were served for explants. MS with $412.5 \mathrm{mg} / \mathrm{l}$ ammonium nitrate, $950 \mathrm{mg} / \mathrm{l}$ potassium nitrate, $20 \mathrm{~g} / \mathrm{l}$ sucrose and $2 \mathrm{~g} / \mathrm{l}$ Phytagel (Sigma) was adjusted to $\mathrm{pH} 5.5$ - 5.8 before autoclaving. Chitosan $\mathrm{H}$ (Kimica, Japan), hyaluronic acid (HA9; Shiseido, Japan) at concentrations of $0,0.1,1$ and $10 \mathrm{mg} / \mathrm{l}$ and different concentrations $(0,0.1,1$ and $10 \mathrm{mg} / \mathrm{l})$ of N6-benzyladenine (BA) were added to media before sterilization. Two hundred fifty $\mathrm{ml}$ of culture jars (UM culture jar, As One, JAPAN) with plastic caps were used, each jar receiving $30 \mathrm{ml}$ of medium. Five explants were put in each culture vessel and three culture vessels were used for each treatment. All cultures were maintained at $25 \pm 2{ }^{\circ} \mathrm{C}$, a $16 \mathrm{hr}$ photoperiod with irradiance of $54 \mu \mathrm{mol} / \mathrm{m}^{-2} \mathrm{~s}^{-1}$ for 40 days. The data were subjected to a one-way analysis of variance (ANOVA) and differences between means were tested using Tukey's honestly significant different test $(\mathrm{p}<0.05)$.

\section{Results and Discussion}

Effects of HA9, chitosan H and BA in modified MS on organogenesis in PLB of Cymbidium Waltz 'Idol' after 40 days of culture is shown in Table 1 and Fig. 1. The highest number of PLBs (12.4) was recorded in the media containing $0.1 \mathrm{mg} / \mathrm{l}$ HA9 and was significantly different $(p<0.05)$ to those of control $(5.1)$, Chitosan 
$\mathrm{H}$ and BA treatments, respectively. PLB formation significantly promoted at BA 1.0 and $10 \mathrm{mg} / \mathrm{l}$, however showed lower number than that of $0.1 \mathrm{mg} / \mathrm{l} \mathrm{HA9}$ treatment. Chitosan $\mathrm{H}$ had no or little effect on increase in PLB number, otherwise had negative effect at $10 \mathrm{mg} / \mathrm{l}$ treatment. Meanwhile, PLBs formation rate showed $100 \%$ at all treatments except for control $(82.7 \%), 0.1 \mathrm{mg} / \mathrm{l} \mathrm{HA9}$ $(93.3 \%)$ and $10 \mathrm{mg} / \mathrm{l}$ Chitosan $\mathrm{H}(93.3 \%)$ treatments.
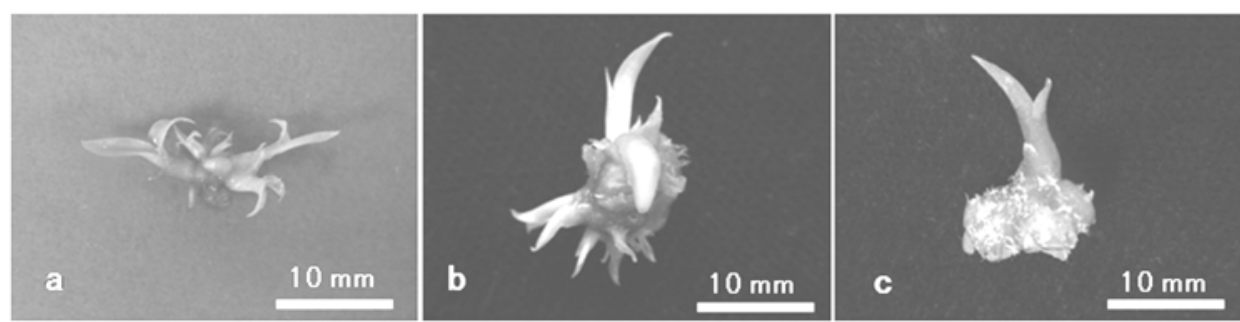

Fig. 1. Effect of HA9, chitosan $\mathrm{H}$ and BA in modified MS on organogenesis in PLB of Cymbidium Waltz 'Idol' after 40 days of culture. a: BA $1.0 \mathrm{mg} / \mathrm{l}, \mathrm{b}$ : HA9 $10 \mathrm{mg} / \mathrm{l}$ : Chitosan H $1.0 \mathrm{mg} / \mathrm{l}($ Bars = $10 \mathrm{~mm})$

Table 1. Effect of HA9, chitosan $H$ and BA on organogenesis in PLB culture of Cymbidium Waltz 'Idol'.

\begin{tabular}{llccccc}
\hline \multirow{2}{*}{$\begin{array}{l}\text { Treatment } \\
(\mathrm{mg} / \mathrm{l})\end{array}$} & & \multicolumn{2}{c}{ PLB } & \multicolumn{2}{c}{ Shoot } & FW \\
\cline { 2 - 5 } & & ${ }^{*}$ Number & $\begin{array}{c}\text { Rate }^{1} \\
(\%)\end{array}$ & ${ }^{*}$ Number & $\begin{array}{c}\text { Rate }^{2} \\
(\%)\end{array}$ & $(\mathrm{mg})$ \\
\hline Control & 0 & $5.1 \pm 0.8^{\mathrm{b}}$ & 82.7 & $1.6 \pm 0.3^{\mathrm{a}}$ & 80.0 & $181.1 \pm 24.3^{\mathrm{a}}$ \\
HA9 & 0.1 & $12.4 \pm 1.1^{\mathrm{d}}$ & 93.3 & $2.4 \pm 0.4^{\mathrm{ab}}$ & 80.0 & $351.2 \pm 45.6^{\mathrm{cd}}$ \\
& 1.0 & $9.5 \pm 1.1^{\mathrm{c}}$ & 100 & $2.7 \pm 0.5^{\mathrm{ab}}$ & 80.0 & $278.5 \pm 29.0^{\mathrm{bc}}$ \\
Chitosan H & 0.1 & $5.8 \pm 0.3^{\mathrm{b}}$ & 100 & $1.6 \pm 0.4^{\mathrm{a}}$ & 73.3 & $261.5 \pm 27.2^{\mathrm{bc}}$ \\
& 1.0 & $5.1 \pm 0.3^{\mathrm{b}}$ & 100 & $2.1 \pm 0.3^{\mathrm{ab}}$ & 100 & $286.1 \pm 24.9^{\mathrm{bc}}$ \\
& 10 & $3.5 \pm 0.6^{\mathrm{a}}$ & 93.3 & $1.5 \pm 0.2^{\mathrm{a}}$ & 86.7 & $173.1 \pm 39.1^{\mathrm{a}}$ \\
BA & 0.1 & $5.7 \pm 0.9^{\mathrm{b}}$ & 100 & $2.7 \pm 0.7^{\mathrm{ab}}$ & 73.3 & $467.3 \pm 72.4^{\mathrm{d}}$ \\
& 1.0 & $7.3 \pm 1.3^{\mathrm{c}}$ & 100 & $3.9 \pm 1.0^{\mathrm{b}}$ & 80.0 & $461.6 \pm 52.8^{\mathrm{d}}$ \\
& 10 & $8.1 \pm 1.1^{\mathrm{c}}$ & 100 & $2.1 \pm 0.7^{\mathrm{ab}}$ & 50.0 & $451.1 \pm 65.8^{\mathrm{d}}$ \\
\hline
\end{tabular}

*Values represent mean \pm SE followed by the different superscript letters show significant differences at $\mathrm{p} \leq 0.05$. The cultures were examined after 40 days of culture. Each treatment consisted of three replicates, and each replicate consisted of $\times 5$ PLBs.

$$
\begin{aligned}
& \text { 1Percentage of PLB formation }=\frac{\text { Number of culture explant with new PLBs }}{\text { Total number of culture explant }} \times 100 \\
& { }^{2} \text { Percentage of shoot formation }=\frac{\text { Number of culture explant with shoot }}{\text { Total number of culture explant }} \times 100
\end{aligned}
$$


These findings indicate that HA9 has the ability to stimulate PLB proliferation of Cymbidium in vitro. In all the media tested for HA9, new PLBs formation occurred within short period of 10 days (data not shown). Higher number of shoot formation indicated in the medium with $1.0 \mathrm{mg} / \mathrm{l} \mathrm{BA}$ (3.9) and $10 \mathrm{mg} / \mathrm{l} \mathrm{HA9}$ (3.6) and significantly different to the control treatment. The maximum percentage of shoot formation was found in medium supplemented with $1 \mathrm{mg} / \mathrm{l}$ Chitosan $\mathrm{H}(100 \%)$. Percentage of shoot formation indicated more than $73.3 \%$ in all treatment except for $10 \mathrm{mg} / \mathrm{l} \mathrm{BA}$ treatment $(50.0 \%)$.

Present authors investigated the effects of two biopolymer elicitors and synthetic plant hormone including hyaluronic acid (HA9), Chitosan $\mathrm{H}$ and BA on PLB and shoot formation of Cymbidium. BA is widely used for micropropagation of orchids because of its ability to induce organogenesis especially shoot regeneration (Shimasaki and Uemoto 1990, Paek and Yeung 1991, Nayak et al. 1997). However, as some reports suggested that high concentrations of BA added in culture medium implicated to increase mutation rate in regenerated plants (Arditti and Ernst 1993, Huetteman and Preece 1993). Modern approach to plant production include application of signals of stress as a strategy to promote not only increase of tolerance, then promote growth of plants (Boughton et al. 2006). Chitosan considered as one of potent elicitors which induce disease tolerance which include giving signaling mechanisms of stress. Plant growth promoted after giving it small or short time of stress by application of elicitor (Ben-Shalom et al. 2003, Photchanachai et al. 2006).

The main aim of this study is to confirm that "Hyaluronic acid" act as new plant growth regulator such as BA and chitosan which induce PLBs, shoots with short duration of time. Effect of chitosan for orchid cultures in vitro have been reported (Nge et al. 2006, Kananont et al. 2010). However, some chitosans with high $\mathrm{pH}$-insolubility in media are difficult to apply for tissue culture. However, it will be not convenient for mass production process of orchid tissue culture. Otherwise, hyaluronic acid shows high solubility in culture medium. It elicits systemic resistance in cucumber, tomato and pepper (Park et al. 2008) and has been one of agents for enhancing secondary metabolite production in plant tissue culture. Present results clearly demonstrated that like BA, if hyaluronic acid added to culture media acts as plant growth regulator to induce PLB and shoot formation of Cymbidium. During 40 days of culture, there was no malformation observed in regenerated shoots. However, possibility of avoiding mutation of cultures in the presence of HA should be confirmed for the establishment of micropropagation system in long span.

Results of this study indicated that some biopolymer type of elicitors such as HA can be used as new plant growth regulator for Cymbidium micropropa- 
gation, because it enhanced both PLB and shoot formation within a short period. Moreover, the use of HA as a plant growth regulator is of interest as it is a safe material for human and environment. Therefore, much more work is still needed to explore the mechanism involved in the PLB formation and to clarify the possibility of genetic variation in the regenerated plants.

\section{References}

Arditti J and Ernst R (1993) In: Micropropagation of orchids. Wiley Publishers, New York, pp. 682

Ben-Shalom N, Ardi R, Pinto R, Aki C and Fallik E (2003) Controlling gray mould caused by Botrytis cinerea in cucumber plants by means of chitosan. Crop Protection. 22: 285-290.

Boughton J, Anthony HK and Felton GW (2006) Impact of chemical elicitor applications on greenhouse tomato plants and population growth of the green peach aphid, Myzus persicae. Entomologia et Applica. 120:175-188.

Fraser JRE, Lauren TC and Laurent UBG (1997) Hyaluronan: its nature, distribution, functions and turnover. J. Int. Medic. 242: 27-33.

Hossain MM, Sharma M, Teixeira da Silva JA and Pathak P (2010) Seed germination and tissue culture of Cymbidium giganteum Wall. Ex Lindl. Scientia Hortic. 123: 479-487.

Huetteman CA and Preece JE (1993) Thidiazuron: a potent cytokinin for woody plant tissue culture. Plant Cell Tissue Organ Cult. 33: 105-119.

Jabun NS, Shimasaki K, Huang CL and Kaewjamp N (2011) Effect of plant growth regulators on organogenesis in protocorm-Like Body (PLBs) of Cymbidium dayanum in vitro. ARPN J. Agril. Biol. Sci. 6: 28-33.

Kananont N, Pichyangkura R, Chanprame S, Chagchawan S, and Limpanavech P (2010) Chitosan specificity for the in vitro seed germination of two Dendrobium orchids (Asparagales: Orchidaceae). Scientia Hortic. 124: 239-247.

Keawjampa N, Shimasaki K, Huang, CL and Jabun NS 2010. Effects of biopolysaccharide on organogenesis in orchid in vitro. Proceeding of The $1^{\text {st }}$ Kamphaengsaen International Natural Products Symposium, The relationship between living organisms and environment, pp. 37-42.

Morel GM (1960) Producing virus-free Cymbidium. American Orchid Society Bulletin. 29: 473-478.

Nasiruddin KM, Begum R, and Yasmin S (2003) Protocorm-like bodies and plantlet regeneration from Dendrobium formosum leaf callus. Asian J. Plant Sci. 2: 955-957

Nayak NR, Patnaik S and Rath SP (1997) Direct shoot regeneration from foliar explants of an epiphytic orchid Acampe praemorsa (Roxb.) Blatter and McCann. Plant Cell Rep. 16: 583-586.

Nge KL, New N, Chandrkrachang, S and Stevens WF (2006) Chitosan as a growth stimulator in orchid tissue culture. Plant Sci. 170: 1185-1190. 
Paek KY and Yeung EC (1991) The effects of 1-naphthalenaecetic acid and Nbenayladenine on the growth of Cymbidium forrestii rhizomes in vitro. Plant Cell Tissue Organ Cult. 24: 65-71.

Park K, Pau D, Kim E and Joseph WKPP (2008) Hyaluronic acid of Streptococcus sp. as a potent elicitor for induction of systemic resistance against plant diseases. World J. Microbiol. Biotechnol. 24: 1153-1158.

Photchanachai S, Singkaew J and Thamthong J (2006) Effects of chitosan seed treatment on Colletotrichum sp. and seedling growth of chili cv. 'Jinda'. Acta Hortic. 712: 585-590.

Pornpienpakdee P, Singhasurasak R, Chaiyasap P, Pichyangkura R, Bunjongrat R, Chadchawan S and Limpanavech P (2010). Improving the micropropagation efficiency of hybrid Dendrobium orchids with chitosan. Scientia Hortic. 124: 490-499.

Scott JE (1992) Supramolecular organization of extracellular matrix glycos-aminoglycans, in vitro and in the tissues. Journal of the Federation of American Societies for Experimental Biology. 6: 2639-2645.

Shimasaki K and Uemoto S (1990) Micropropagation of a terrestrial Cymbidium species using rhizomes developed from seeds and pseudobulbs. Plant Cell Tissue Organ Cult. 22: 237-244.

Shimasaki K, Tanibuchi Y and Fukumoto Y (2003) The effects of chitosan on organogenesis in protocorm-like body (PLB) of Cymbidium finlaysonianum Lindl. J. Societies of High Technology in Agriculture. 15: 90-93.

Teixeira de Silva JA, Singh N and Tanaka M (2006a) Priming biotic factors for optimal protocorm-like body and callus induction in hybrid Cymbidium (Orchidaceae), and assessment of cytogenetic stability in regenerated plantlets. Plant Cell Tissue Organ Cult. 84: 135-144.

Teixeira de Silva JA, Chan MT, Sanjava Chai ML and Tanaka M (2006b) Priming abiotic factors for optimal hybrid Cymbidium (Orchidaceae) PLB and callus induction, plantlet formation, and their subsequent cytogenetic stability analysis. Scientia Hortic. 109: 368-378. 